\title{
Sporothrix spp. EVALUATION IN SOIL OF A HYPERENDENIC AREA FOR SPOROTRICHOSIS IN SOUTHERN BRAZIL
}

\author{
AVALIAÇÃO DA PRESENÇA DE Sporothrix spp. EM SOLO DE ÁREA \\ HIPERENDÊMICA PARA ESPOROTRICOSE NO EXTREMO SUL DO BRASIL
}

\author{
Vanice Rodrigues Poester ${ }^{1}$ \\ Josiara Furtado Mendes ${ }^{1}$ \\ Andrea Von Groll ${ }^{1}$ \\ Gabriel Baracy Klafke ${ }^{1}$ \\ Tchana Martinez Brandolt ${ }^{1}$ \\ Melissa Orzechowski Xavier ${ }^{1^{*}}$ \\ ${ }^{1}$ Federal University of Rio Grande (FAMED-FURG), Rio Grande, RS, Brazil; \\ *Autora para correspondência - melissaxavierfurg@gmail.com
}

\begin{abstract}
The increase in zoonotic sporotrichosis cases has become a public health problem in hyperendemic areas for the feline disease. Domestic cats involvement in this transmission and the continuous contact of these animals with soil suggest that the environment may be an essential source and/or reservoir of Sporothrix spp. Thus, the current study aimed to evaluate the presence of Sporothrix spp. in the soil of places where infected cats in Southern Brazil is present. In total, 101 soil samples were collected from the residence of cats with sporotrichosis, from regions around to these residences, and also from public places. These samples were processed using the direct plating technique being incubated at $25^{\circ} \mathrm{C}$ for up to 15 days. Additionally, seventeen samples were also submitted to DNA extraction (NORGEN BIOTEK CORP ${ }^{\circledR}$ kit), PCR-specific and Nested-PCR technique. Although the presence of Sporothrix in soil has been undetected, by culture or molecular biology, this study does not reject the role of the environment in the triad of the infectious process (soil-animal-human). Thus, further studies are necessary for expanding the area of coverage, volume, type and method of sampling, and/or detection techniques.
\end{abstract}

Keywords: environment; geophilic; S. brasiliensis; S. schenckii

\section{Resumo}

O aumento de casos de esporotricose zoonótica tornou-se um problema de saúde pública em áreas hiperendêmicas para a doença em felinos. O envolvimento dos gatos domésticos nesta transmissão e o contato contínuo destes animais com o solo sugerem que o ambiente possa ser uma importante fonte e/ou reservatório de fungos Sporothrix spp. Assim, este estudo objetivou avaliar a presença de fungos do complexo Sporothrix em amostras de solo provenientes de locais de acesso de felinos infectados no sul do Brasil. Foram coletadas amostras de solo de residências com felinos com esporotricose, de locais próximos a estas residências e também de locais públicos, totalizando 101 amostras. Estas foram processadas pela técnica de plaqueamento direto e incubadas a $25^{\circ} \mathrm{C}$ por até 15 dias. Dezessete amostras foram paralelamente submetidas a extração de DNA (kitNORGEN BIOTEK CORP®) e 
técnica de PCR espécie-específico e Nested-PCR. Embora em nenhuma amostra avaliada tenha sido detectada a presença de Sporothrix spp., seja por cultivo ou por biologia molecular, este estudo não descarta o papel do ambiente na tríade do processo infeccioso (solo - animal - humano), sendo necessários outros estudos ampliando área de abrangência, volume, tipo e método de coleta das amostras, bem como técnicas de detecção.

Palavras-chave: Ambiente; geofílico; S. brasiliensis; S. schenckii.

Received: April 19, 2018.

Accepted: September 18, 2018

\section{Introduction}

The increase in the number of zoonotic sporotrichosis in the last decade has become a problem for public health in feline sporotrichosis hyperendemic areas ${ }^{(1,2)}$. This alarming increase was due to the involvement of domestic cats (Felis Catus) in the transmission of the disease ${ }^{(3)}$, with outbreaks described in the states of Rio de Janeiro, São Paulo, and Rio Grande do Sul ${ }^{(4-6)}$. In the literature, studies with the isolation of the Sporothrix complex from clinical samples (human and feline) are widely described ${ }^{(6-8)}$. Further, the primary sources of infection were demonstrated to be directly related to the causal species, being the sapronotic cases in Brazil, generally associated with the species S. schenckii strictu sensu and S. globosa, and the animal and zoonotic cases related to S. brasiliensis species $^{(9)}$.

However, S. brasiliensis is not taken into consideration geophysically, like other species of the complex ( $S$. schenckii strictu sensu, S. globosa, S. mexicana, etc.), leading to hypothesize that the environment can also have a function as a reservoir for this species in hyperendemic areas of feline sporotrichosis $^{(2,10,11)}$. Transfer of $S$. brasiliensis from the sick animal to the environment could occur in three ways: (i) by contact of animal lesions with the surrounding environment, considering the massive quantities of fungal propagules in these injuries, (ii) by feces of sick felines that can carry viable propagules of the fungus, or (iii) by the human habit of burying the bodies of animals that come to death by disease ${ }^{(4,5,10)}$.

Environmental studies with the isolation of this fungal complex are scarce in the literature ${ }^{(2)}$. However, there is an urgent need to enable a better understanding of the potential sources of infection and the ecology of Sporothrix spp. in nature. Indeed, this information would contribute towards a better approach to the environment-feline-human triad, assisting in controlling the current epidemic situation of sporotrichosis in hyperendemic states ${ }^{(2,12)}$. Therefore, the study aims to evaluate the presence of the Sporothrix complex in soil samples from a hyperendemic area for feline sporotrichosis in southern Brazil.

\section{Material and Methods}

The study took place in Rio Grande city (Figure 1), which is located on the southern coast of Rio Grande do Sul state, Brazil, with an extension of 2,709,522 $\mathrm{km}^{2}$. Further, the location of the municipality is between the Mirim Lagoon and the Patos Lagoon, which is the largest lagoon in 
Brazil. Additionally, the municipality covers Cassino Beach, which has $250 \mathrm{~km}$ of coastline of the Atlantic Ocean. The estimated population of the municipality by the Brazilian Institute of Geography and Statistics (IBGE) is 208,641 inhabitants ${ }^{(13)}$. It presents subtropical climate, with an average annual temperature of $18,2^{\circ} \mathrm{C}$, and abundant precipitations during the year, being able to undergo direct influences of the El Nino and La Nina phenomena ${ }^{(14)}$.

Samples studied consisted of 50-100g of soil from yard of the residences with feline sporotrichosis, as well as places close to these residences (radius of $10 \mathrm{~m}$ ), in addition to, public places, such as, squares and beach. In total, 101 samples were taken into consideration, of which 42 were from residences, 29 from the close proximity of these residences, and 30 from public places (Figure 2).

The owner mentioned the choice of site for soil collection, indicating as to the preferred environment of the infected feline, with the one that this animal uses for defecation. From this site, the samples were collected systematically by acquiring it from a predetermined rectangular square, where the four corners and the center were sampled according to Moura et al. ${ }^{(15)}$. Residences search was active by being in contact with the owners for authorization of the collection in a maximum period of seven days after the laboratory confirmation of the cases of feline sporotrichosis, diagnosed in the Laboratory of Mycology of the Faculty of Medicine (FAMED) of the Federal University of Rio Grande (FURG).

The definition of places as proximity to the residences was given by taking into consideration external regions within the perimeter of the domicile with the radius of the collection up to $10 \mathrm{~m}$. Further, these samples were also collected methodically with five points defined from the rectangular square. Moreover, in public places, an area of approximately $2 \mathrm{~m}^{2}$ was delimited, where five systematically chosen points were collected too. Samples were collected by surface scraping using sterile spatulas, stored in sterile vials and processed in the Laboratory of Mycology (FAMED-FURG) within a maximum of 12 hours after collection.

For the processing was used the methodology of direct plating, as described by Mehta et al. ${ }^{(16)}$ and Criseo \& Romeo ${ }^{(17)}$, using duplicates of five grams of soil. Colonies that presented morphology, suggestive of Sporothrix sp. after 15 days of incubation at $30^{\circ} \mathrm{C}$, were subcultured by the exhaustion technique to obtain pure cultures, followed by their subsequent identification. The identification was performed by the Polymerase Chain Reaction technique (PCR), with the species-specific primers for species S. brasiliensis, S. schenckii, S. globosa, S. mexicana, and S. pallida ${ }^{(18)}$.

Additionally, soils of seventeen residences of diseased felines were selected by the type of clinical presentation of feline sporotrichosis, together with the massive numbers of animals in the residence and with the locality of neighborhoods with high incidence of the disease ${ }^{(6)}$, for extraction of DNA directly from the soil, using the extraction kit NORGEN BIOTEK CORP® (Canada). DNA samples were submitted to species-specific PCR for the same species described above ${ }^{(18)}$, and were evaluated by the Nested-PCR technique, using the CL1 and CL2A primers in the first cycle and, in the second cycle, the species-specific primers, in order to increase the accuracy for the detection of Sporothrix sp. ${ }^{(18,19)}$. 


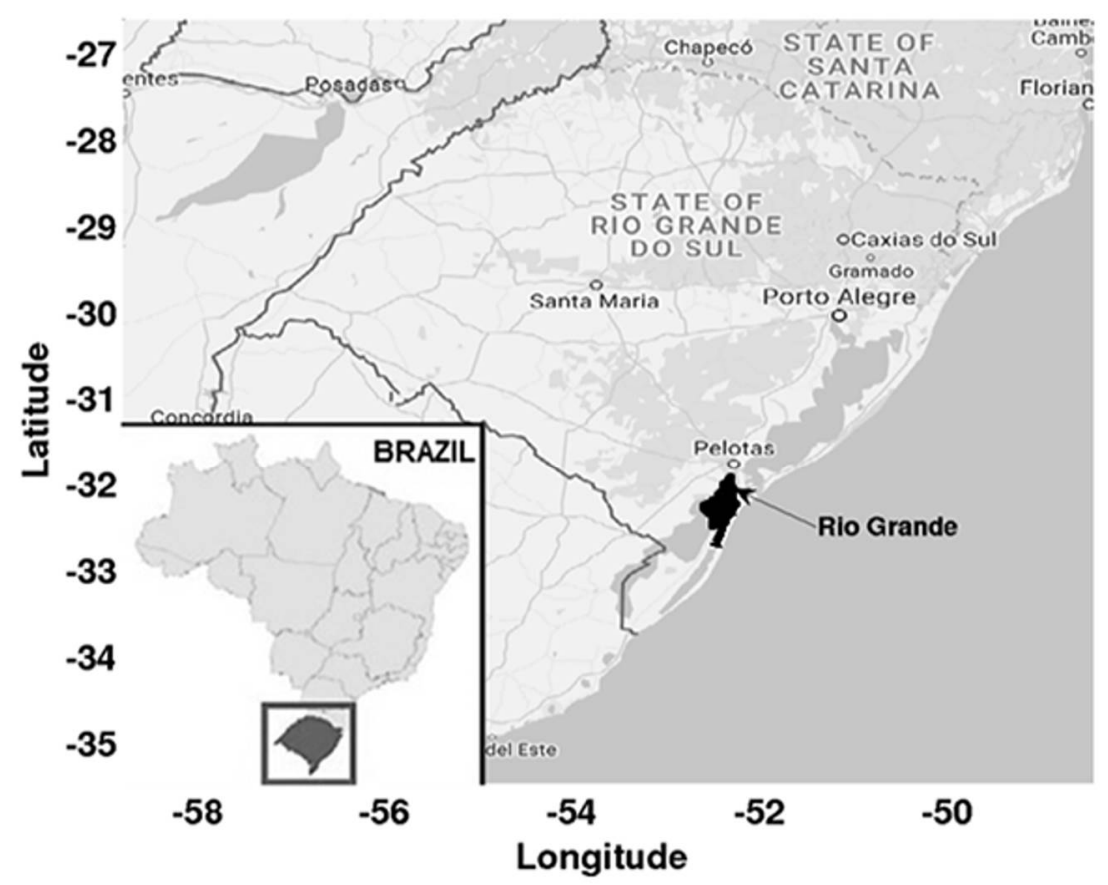

Figure 1. Places of study; Rio Grande, Rio Grande do Sul, and Brazil.

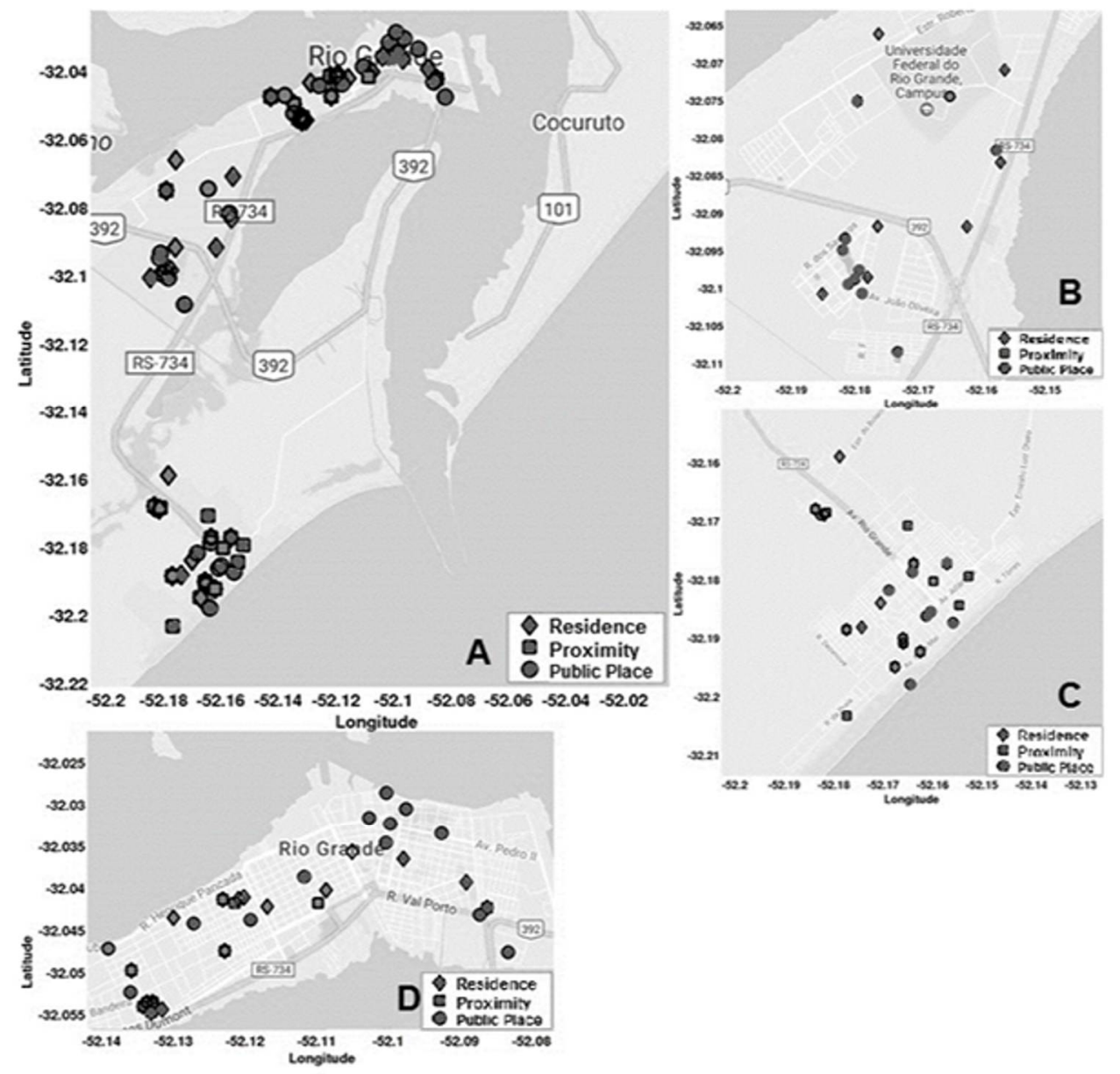

Figure 2. Map demonstrating the soil collection points in the municipality of Rio Grande/RS, Brazil. A. Map covering all points; B. Map zoomed in the neighborhoods of Vila Maria, Carreiros, ParqueMarinha and Parque São Pedro. C. Map zoomed on Casino Beach; D. Map zoomed in the districts of the center of the municipality. 


\section{Results and discussion}

In 26 of the 101 samples studied it was possible to isolate fungi morphologically (macro and microscopy) suggestive of Sporothrix spp., however with unconfirmed identification after the use of the molecular biology technique. Therefore, there was no isolation of fungi from the Sporothrix complex of the loam under analysis. Moreover, the seventeen soils subjected to DNA extraction and direct analysis by molecular biology (PCR and Nested-PCR) were also found to be negative for the five species of the Sporothrix complex analyzed.

Non-isolation and/or detection of Sporothrix complex species having significance in the medical mycology of soils from a hyperendemic area for feline sporotrichosis could indicate a minimal role of this habitat for the maintenance and increment of cases of the disease in this area. However, this data is in disagreement with other studies using the same direct plating technique, in which the rate of isolation of Sporothrix spp. was $15 \%$ and $27 \%$. $^{(16,17)}$.

The municipality of study is a coastal city, where the soil is predominantly sandy, with little organic matter stored, which may be a limiting factor for the growth of Sporothrix spp. ${ }^{(11,20)}$. Furthermore, another possible limiting factor for the growth of these microorganisms in this region is the annual average temperature of $18.2^{\circ} \mathrm{C}$, while in the months of winter; the municipality may present negative temperatures ${ }^{(14)}$. Even though these hypotheses, it is well known that Sporothrix spp. are dimorphic fungi of moderate growth time, and their detection in soil samples per culture is difficult to perform due to the abundant growth of numerous other saprobic microorganisms that can grow fast thereby competing for the nutrients, which is probably the determining cause for the $100 \%$ negative result ${ }^{(4,}$ 21). The other method used in the study is detection of DNA directly from the soil samples, although it is more efficient than the cultivation ${ }^{(2)}$, it was applied only in seventeen samples collected, due to its high cost, with all of seventeen samples being equally negative.

Indeed, molecular techniques, for environmental fungal detection, present superior accuracy in comparison to microbiological techniques ${ }^{(16,17,23)}$. Further, the present study was incapable of detecting Sporothrix spp. in soils analyzed by PCR, which in turn indicates that this negative finding may be in association with the small number of samples evaluated by this method. The higher accuracy of molecular techniques is related to the detection of only fungal DNA, and not to the viable organism. Moreover, the detection of only DNA reveals that this detection is not limited by the presence of other competing microorganisms in the sample, as found in microbiological techniques (Figure 3). Other advantages are the requirement of smaller amounts of fungal cells for DNA detection with the subsequent need of a less number of samples than in microbiological methods which require an enormous number of cells for fungal isolation (Figure 3$)^{(16,17,22,23)}$.

Environmental studies with Sporothrix complex are important for understanding the current epidemiological panorama of the disease in hyperendemic areas $(2,10,11)$. However, studies of the isolation of these fungi from environmentalsamples are scarce, probably because of the difficulty of isolating them from this habitat ${ }^{(11,16,17)}$. Although the present study indicates possible nonenvironmental contamination by Sporothrix sp. in the municipality studied, this non-isolation may be related to limitations of the methodology used (size, type, and coverage of the samples, among others), whereas the transmission of these fungi from plant surfaces is already well established ${ }^{(10)}$. Therefore, regarding the greater accuracy of the molecular detection method, it is instigated to carry 
out broader environmental studies in the region using this method preferably.
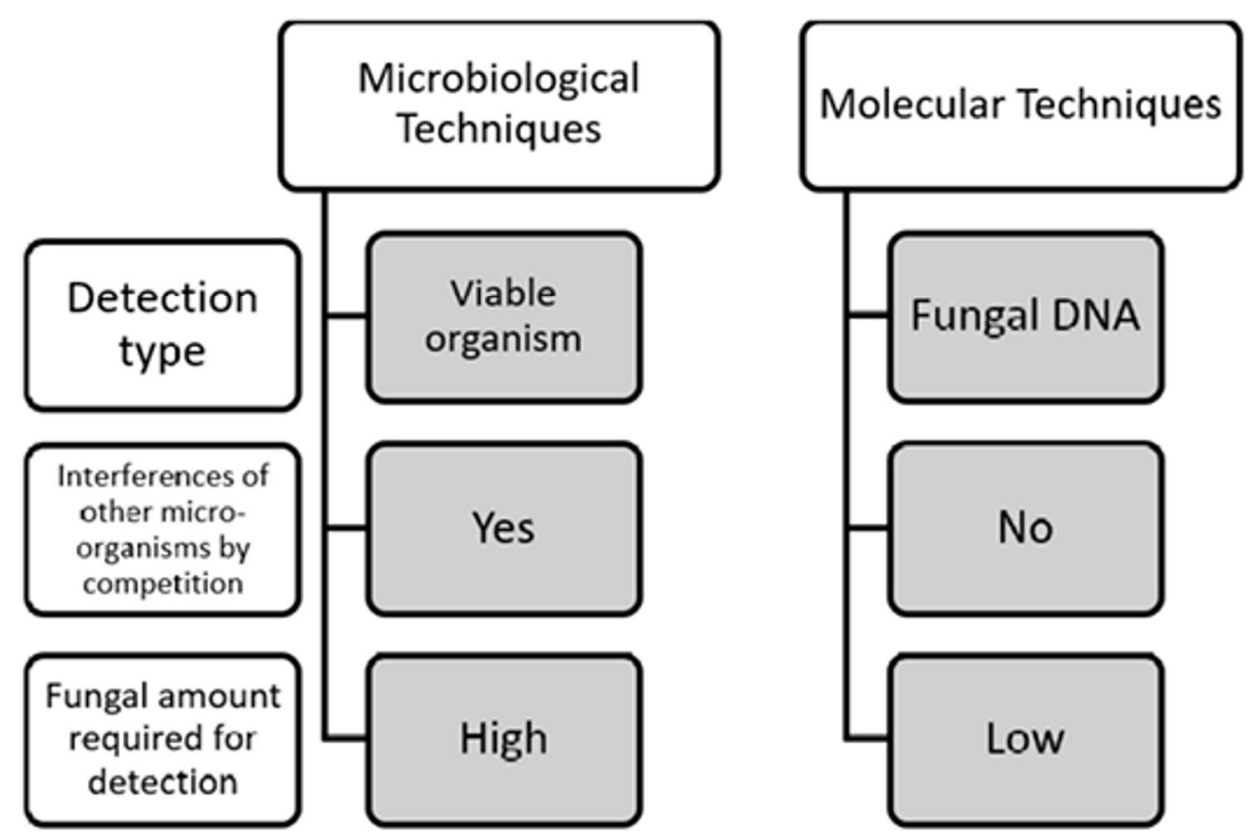

Figure 3. Comparison of microbiological and molecular techmiques for the isolation of fungi from the environment.

\section{Acknowledgement}

The authors are grateful to the Coordenação de Aperfeiçoamento de Pessoal de Nivel Superior (CAPES) for granting scholarships.

\section{References}

1. Silva MBT, Costa MM de M, Torres CC da S, Galhardo MCG, do Valle ACF, Magalhães M de AFM, et al. Esporotricose urbana: Epidemia negligenciada no Rio de Janeiro, Brasil. Cad Saúde Pública. 2012;28(10):1867-80.

2. Rodrigues AM, Teixeira M de M, de Hoog GS, Schubach TMP, Pereira SA, Fernandes GF, et al. Phylogenetic analysis reveals a high prevalence of Sporothrix_brasiliensis in feline sporotrichosis outbreaks. PLoS Negl Trop Dis [Internet]. 2013;7(6):e2281. Available from: http://www.pubmedcentral.nih.gov/articlerender.fcgi?artid=3688539\&tool=pmcentrez\&rendertype=abstract

3. Barros MB, Schubach A de O, do Valle AC, Gutierrez Galhardo MC, Conceição-Silva F, Schubach TM, et al. Cat-transmitted sporotrichosis epidemic in Rio de Janeiro, Brazil: description of a series of cases. Clin Infect Dis. 2004;38:529-35.

4. Montenegro H, Rodrigues AM, Dias MAG, da Silva EA, Bernardi F, de Camargo ZP. Feline sporotrichosis due to Sporothrix brasiliensis: an emerging animal infection in São Paulo, Brazil. BMC Vet Res [Internet]. 2014;10:269.

Available

from:

http://www.pubmedcentral.nih.gov/articlerender.fcgi? artid=4244058\&tool=pmcentrez\&rendertype=abstract 
5. Pereira SA, Gremião IDF, Kitada AAB, Boechat JS, Viana PG, Schubach TMP. The epidemiological scenario of feline sporotrichosis in Rio de Janeiro, State of Rio de Janeiro, Brazil. Rev Soc Bras Med Trop. 2014;47(3):392-3.

6. Sanchotene KO, Madrid IM, Klafke GB, Bergamashi M, Terra PPD, Rodrigues AM, et al. Sporothrix brasiliensis outbreaks and the rapid emergence of feline sporotrichosis. Mycoses. 2015;58(11):652-8.

7. Madrid IM, Mattei AS, Fernandes CG, Oliveira Nobre M, Meireles MCA. Epidemiological findings and laboratory evaluation of sporotrichosis: a description of 103 cases in cats and dogs in Southern Brazil. Mycopathologia. 2012;173:265-73.

8. Almeida-Paes R, de Oliveira MME, Freitas DFS, do Valle ACF, Zancopé-Oliveira RM, Gutierrez-Galhardo MC. Sporotrichosis in Rio de Janeiro, Brazil: Sporothrix brasiliensis is associated with atypical clinical presentations. PLoS Neg1 Trop Dis [Internet]. 2014;8(9):e3094. Available from: http://www.pubmedcentral.nih.gov/articlerender.fcgi?artid=4169245\&tool=pmcentrez\&rendertype=abstract

9. Rodrigues AM, de Hoog GS, de Camargo ZP. Sporothrix Species Causing Outbreaks in Animals and Humans Driven by Animal-Animal Transmission. PLoS Pathog [Internet]. 2016;12(7):e1005638. Available from:

http://www.pubmedcentral.nih.gov/articlerender.fcgi?artid=4945023\&tool=pmcentrez\&rendertype=abstract

10. Barros MBDL, de Almeida Paes R, Schubach AO. Sporothrix schenckii and Sporotrichosis. Clin Microbiol Rev [Internet]. 2011;24(4):633-54. Available from: http://www.pubmedcentral.nih.gov/articlerender.fcgi?artid=3194828\&tool=pmcentrez\&rendertype=abstract

11. Téllez MD, Batista-Duharte a, Portuondo D, Quinello C, Bonne-Hernández R, Carlos IZ. Sporothrix schenckii complex biology: environment and fungal pathogenicity. Microbiology [Internet]. 2014;160(Pt 11):2352-65. Available from: http://www.ncbi.nlm.nih.gov/pubmed/25135886

12. Barros MBL, Schubach AO, Schubach TMP, Wanke B, Lambert-Passos SR. An epidemic of sporotrichosis in Rio de Janeiro, Brazil: epidemiological aspects of a series of cases. Epidemiol Infect [Internet]. 2008;136(9):1192-6. Available from: http://www.pubmedcentral.nih.gov/articlerender.fcgi?artid=2870916\&tool=pmcentrez\&rendertype=abstract

13. IBGE, Instituto Brasileiro de Geografia e Estatística. Censo Demográfico 2010 [Internet]. 2016. Available from: http://cidades.ibge.gov.br/xtras/perfil.php?codmun=431560

14. Instituto Nacional de Meteorologia INMET. Temperatura Média Compensada $\left({ }^{\circ} \mathrm{C}\right)$.

15. de Moura MQ, Jeske S, Vieira JN, Corrêa TG, Berne MEA, Villela MM. Frequency of geo helminths in public squares in Pelotas, RS, Brazil. Rev Bras Parasitol Veterinária [Internet]. 2013;22(1):175-8. Available from: $\quad$ http://www.scielo.br/scielo.php?script=sci arttext\&pid=S198429612013000100175\&lng=en\&nrm=iso\&tlng=en

16. Mehta KIS, Sharma NL, Kanga AK, Mahajan VK, Ranjan N. Isolation of Sporothrix schenckii from the environmental sources of cutaneous sporotrichosis patients in Himachal Pradesh, India: results of a pilot study. Mycoses [Internet]. 2007;50(6):496-501. Available from: http://www.ncbi.nlm.nih.gov/pubmed/17944713

17. Criseo G, Romeo O. Ribossomal DNA sequencing and phylogenetic analysis of environmental Sporothrix schenckii strains: comparison with clinical isolates. Mycopathologia. 2010;169:351-8.

18. Rodrigues AM, Hoog GS, Camargo ZP. Molecular Diagnosis of Pathogenic Sporothrix Species. PLoS Negl Trop Dis [Internet]. 2015;9(12):e0004190. Available from: http://www.pubmedcentral.nih.gov/articlerender.fcgi?artid=4666615\&tool=pmcentrez\&rendertype=abstract

19. Rodrigues AM, de Hoog GS, de Camargo ZP. Genotyping species of the Sporothrix schenckii complex by PCR-RFLP of calmodulin. Diagn Microbiol Infect Dis [Internet]. Elsevier Inc.; 2014;78(4):383-7. Available 
from: http://www.ncbi.nlm.nih.gov/pubmed/24525143

20. Cunha NG da, Silveira RJ da C, Severo CRS. Estudo dos solos do município de Rio Grande. Pelotas; 1996.

21. Lopes-Bezerra L, Schubach A, Costa R. Sporothrix schenckii and sporotrichosis. In: An Acad Bras Ciênc. 2006: p. 293-308.

22. Bridge P, Spooner B. Soil fungi : diversity and detection. Plant Soil. 2001;232:147-54.

23. O’Brien HE, Parrent JL, Jackson JA, Moncalvo J, Vilgalys R. Fungal Community Analysis by Large-Scale Sequencing of Environmental Samples. Appl Environ Microbiol [Internet]. 2005;71(9):5544-50. Available from: http://aem.asm.org.ezproxy.leidenuniv.nl:2048/content/71/9/5544 